\title{
The first record of paguroids from the Eocene of Istria (Croatia) and further phylogenetic refinement of the Paguroidea (Crustacea, Anomura)
}

\author{
Rok GaŠParič, René H.B. FraAiJe, NinON RobIn \& ANTONIO De Angel
}

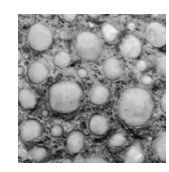

\begin{abstract}
A paguroid, Lessinipagurus vasjamikuzi sp. nov., is described from Eocene (upper Bartonian-lower Priabonian) of Istria, on the basis of a single right chela from Gračišće near Pazin, western Croatia. The specimen originates from beds of olistostrome breccias that formed in a bathyal setting. In addition, a new genus, Prexylopagurus, accommodated in the new family Xylopaguridae, is erected; based on a distinctive set of characters of the dorsal carapace, chelae, and operculate tergite of sixth abdominal somite. The phylogenetic relationships of the new family Xylopaguridae are discussed; it appears to have originated in the Tethyan Realm, possibly as early as the Jurassic, and displays a Tethyan distribution during the Cenozoic. Three extant species are transferred to the new genus, resulting in three new combinations: Prexylopagurus anthonii, $P$. philippinensis, and $P$. caledonicus. The palaeoecology and palaeobiogeography of the newly erected taxa are discussed. The bloom of diversity of Lessinipagurus during the late Eocene parallels the evolution and subsequent ecological expansion of grasses, especially of reed and bamboo, thus constituting a rare example of coevolution between land plants and marine organisms. The holotype of Lessinipagurus vasjamikuzi sp. nov. shows remains of an interesting syn-vivo balanomorph association; this is the earliest record of such barnacles on a decapod crustacean in the fossil record, and the sole record from an anomuran to date. Key words: hermit crabs, Paguroidea, Paleogene, palaeoecology, coevolution.
\end{abstract}

GAŠPARIČ, R., FRAAIJE, R.H.B., RoBIN, N. \& DE ANGELI, A. 2016. The first record of paguroids from the Eocene of Istria (Croatia) and further phylogenetic refinement of the Paguroidea (Crustacea, Anomura). Bulletin of Geosciences 91(3), 467-480 (8 figures). Czech Geological Survey, Prague. ISBN 1214-1119. Manuscript received May 16, 2016; accepted in revised form August 24, 2016; published online September 27, 2016; issued November 25, 2016.

Rok Gašparič (corresponding author), Oertijdmuseum De Groene Poort, Bosscheweg 80, 5293 WB Boxtel, the Netherlands; rok.gasparic@gmail.com • René H.B. Fraaije, Oertijdmuseum De Groene Poort, Bosscheweg 80, 5293 WB Boxtel, the Netherlands; info@oertijdmuseum.nl • Ninon Robin, Muséum national d'Histoire naturelle, Centre de Recherches sur la Paléobiodiversité et les Paléoenvironnements (CR2P, UMR 7207), Sorbonne Universités-MNHN, CNRS, UPMC-Paris 6, 8 rue Buffon, 75005, Paris, France; ninon.robin@edu.mnhn.fr • Antonio De Angeli, Piazzetta Nostro Tetto 9, 36100 Vicenza, Italy; antonio.deangeli@alice.it

The present specimen constitutes the first fossil of an anomuran to be recorded from Eocene strata of Istria (Croatia, Slovenia). Coeval brachyurans have previously been described from several localities in Istria (Bittner 1880; Bachmayer \& Nosan 1959; Mikuž 2002, 2003; Schweitzer et al. 2005) from the so-called "Marls with Crabs". Despite the fact that the region could be expected to contain rich and diverse decapod crustacean assemblages, similar to those from the middle and upper Eocene of nearby Italy (e.g., Beschin et al. 2010, Busulini et al. 2012), middle-late Eocene faunas in Istria are monotonous. Previously recorded fossil brachyurans belong predominantly to the genera Harpactocarcinus A. Milne-Edwards, 1862 and Harpactoxanthopsis Via, 1959, while specimens of Lophoranina Fabiani, 1910, are less common (Schweitzer et al. 2005, Mikuž 2010a).
The olistostrome breccia beds as exposed at Gračišće near Pazin are well known for their diverse Eocene macrofaunas that comprise plant remains, nummulitid foraminifera, coralline algae, corals, polychaetes, bivalves, gastropods and rare decapod crustaceans (Mikuž 2005, 2006, 2008a, b, 2010b; Mikuž et al. 2014). Until recently, only individuals of Harpactoxanthopsis quadrilobata (see Mikuž 2002), and Lophoranina marestiana (see Mikuž 2003) were recorded from the olistostrome levels at Gračišće.

The present hermit crab is assigned to the genus Lessinipagurus Beschin, De Angeli, Checchi \& Zarantonello, 2012, which had been known exclusively from isolated chelipeds in Eocene strata of Italy (Beschin et al. 2012) that all resemble chelae of the extant genus Xylopagurus A. Milne-Edwards, 1880, all species of which 
inhabit the Indo-Pacific and western Atlantic oceans (Forest 1997). Extant forms live in tube-shaped cavities such as pieces of driftwood, hollow pieces of reed or of bamboo (Lemaitre 1995). When lodged in its dwelling, these hermit crabs protect the anterior opening with their distinct strong and rounded right cheliped, while the posterior opening is tightly sealed off by the calcified operculate tergite of the sixth abdominal somite (Lemaitre \& Campos 1993).

All species of Lessinipagurus, including the new one described below, are united by the highly characteristic gouge-shaped anterior morphology of the right cheliped which is due to the presence of a pseudo-fixed finger that extends parallel to the outer side of the dactylus. This phenomenon is also seen in extant species of Xylopagurus. Lemaitre (1995, p. 23) stated that, "several structures in species of Xylopagurus are unusual or unique among hermit crabs. The length of the linea $d$ (= decalcified submassetic groove) as seen in $X$. anthonii, for example, is greater than is known in other hermit crabs. The most visible and striking structure found in species of Xylopagurus is the strongly calcified and operculate tergite of the sixth abdominal somite". The same author also pointed out (p. 2) that, "on either side of the posterior region of the cephalic shield there is a shallow pit; they are referred to as the posterior gastric pits". These gastric pits are also seen in illustrations provided in two other recent studies on Xylopagurus by Lemaitre \& Campos (1993) and Forest (1997), albeit not mentioned in the descriptive part of those papers. Although Xylopagurus was assigned to the Paguridae Latreille, 1802 by de Saint LaurentDechancé (1966) and Provenzano (1971), the systematic position of this genus is still a matter of discussion (Lemaitre 1995).

\section{Stratigraphical and geographical setting}

Predominant Eocene strata in Istria comprise a clastic flysch sequence and pelagic foraminiferal limestones (Fig.1A). The majority of known macrofossil localities are situated around the contact of both lithologies (Mikuž et al. 2014), where the foraminiferal limestones grade into the flysch and are therefore called "Transitional Beds". These "Transitional Beds" (commonly called also "Marls with Crabs") consist of calcareous marls, Globigerina marls, and breccias, which are conformably overlain by the more coarsely grained flysch beds (Živkovic \& Glumac 2007). The 20-km-wide belt of flysch sediments extends from Ankaran (Slovenia) in the northwest, to Labin (Croatia) in the southeast (Mikuž et al. 2014).

The fossiliferous olistostrome breccia beds at Gračišće near Pazin formed in the Trieste-Pazin Basin. The Trieste-Pazin, a foreland basin of Alpine type with typical marine flysch deposits (Živkovic \& Glumac 2007). The ba- sin came into existence during the early to middle Eocene as a result of subduction and closure of the Tethys Ocean (Babić \& Zupanič 1996). The transitional "Marls with Crabs" are interpreted to reflect a gradual deepening from a shelf carbonate platform to bathyal environments (Juračić 1979, Ćosović et al. 2004). The upper part of these beds consists of several tens of metres of hemipelagic Globigerina marls, which are conformably overlain by coarser flysch beds, including the olistostrome breccia (Fig. 1B) discussed herein (Marinčić et al. 1996).

Nannoplankton analyses from the olistostrome breccia horizon were performed by Mikuž et al. (2014); these yielded a rich assemblage containing, amongst other taxa Chiasmolithus solitus (Bramlette \& Sullivan 1961), Sphenolithus obtusus (Bukry 1971) and Helicosphaera compacta (Bramlette \& Wilcoxon 1967). The co-occurrence of these coccolith species allows the assignment of the olistostrome breccia to the lower part of biozone NP17 (Martini 1971) or CP14b (Okada \& Bukry 1980), which are dated as late Bartonian to early Priabonian (Pavšič \& Premec Fuček 2000).

\section{Institutional abbreviations}

To indicate the repositories of specimens presented below, the following abbreviations are used: AO - Ŕlex Ossó fossil crab collection, Tarragona, Catalonia; MAB - Oertijdmuseum De Groene Poort, Boxtel, the Netherlands; MCZMuseo Civico "G. Zannato", Montecchio Maggiore (Vicenza), Italy; NHMUK - The Natural History Museum, Department of Palaeontology, London, United Kingdom; RGA/SMNH - Slovenian Museum of Natural History, Ljubljana, Slovenia (R. Gašparič Collection).

\section{Systematic palaeontology}

Order Decapoda Latreille, 1802

Infraorder Anomura MacLeay, 1838

Superfamily Paguroidea Latreille, 1802

Family Xylopaguridae fam. nov.

Type genus. - Xylopagurus A. Milne-Edwards, 1880.

Included genera. - In addition to the type genus, Lessinipagurus Beschin, De Angeli, Checchi \& Zarantonello, 2012 and Prexylopagurus gen. nov. The taxon Paguritergites Fraaije, Artal, Van Bakel, Jagt \& Klompmaker, 2013, which was erected based on a sixth abdominal somite, also belongs here, but so far this somite type has not been linked to either a carapace or cephalic shield or chelae. 



Mesozoic carbonates

Eocene foraminiferal limestones

Eocene flysch

Figure 1. A - geographical position of the locality and simplified geological sketch of Eocene strata of Istria (after Živkovic \& Glumac 2007). - B - stratigraphical column indicating the level of provenance of Lessinipagurus vasjamikuzi sp. nov.

Stratigraphical range. - The earliest record of a xylopagurid is that of an abdominal tergite as recorded by Fraaije et al. (2013) from the upper Albian of northwest Spain. The type, and sole specimen known, is Paguritergites yvonnecooleae Fraaije, Artal, Van Bakel, Jagt \& Klompmaker, 2013; this constitutes a subquadratic, well-calcified and plate-like tergite divided into four subequal quadrants by anterior and posterior longitudinal median grooves and a median or transverse depression, similar to all known extant species of Xylopagurus.

Diagnosis. - Elongated subcylindrical carapace; shield longer than posterior part of carapace; gastric region shaped like an arrowhead pointing posteriorly with presence of gastric pits at about widest part; operculate, subquadratic, plate-like tergite of sixth abdominal somite strongly calcified, divided into four equal or subequal quadrants; chelipeds markedly dissimilar, right cheliped strong, massive with a pseudo-fixed finger extending parallel to the outer side of the dactylus.

Remarks. - Although Xylopagurus has previously been placed, albeit provisionally, in the Paguridae, the systematic position of the genus still is under debate (Lemaitre 1995). Lemaitre's landmark study of Xylopagurus noted several structures in its constituent species that were unusual or unique amongst extant hermit crabs. The combination of an elongated subcylindrical carapace, a shield that is longer than the posterior part of the carapace; a gastric region shaped like an arrowhead pointing posteriorly with the presence of gastric pits at about its widest part; a tergite of the sixth abdominal somite that is a strongly calcified, operculate, plate-like structure divided into four equal or subequal quadrants by anterior and posterior longitudinal median grooves and a median or submedian transverse depression; chelipeds that are markedly dissimilar; the strong, massive right cheliped with a pseudo-fixed finger extending parallel to the outer side of the dactylus (Fig. 2A-I), warrants the erection of the new paguroid family; Xylopaguridae.

A comparison of xylopagurid carapace morphology with the extensive record of carapaces of extinct paguroids discovered during the last decade (e.g., Fraaije 2014) reveals a close affinity with the Parapylochelidae 

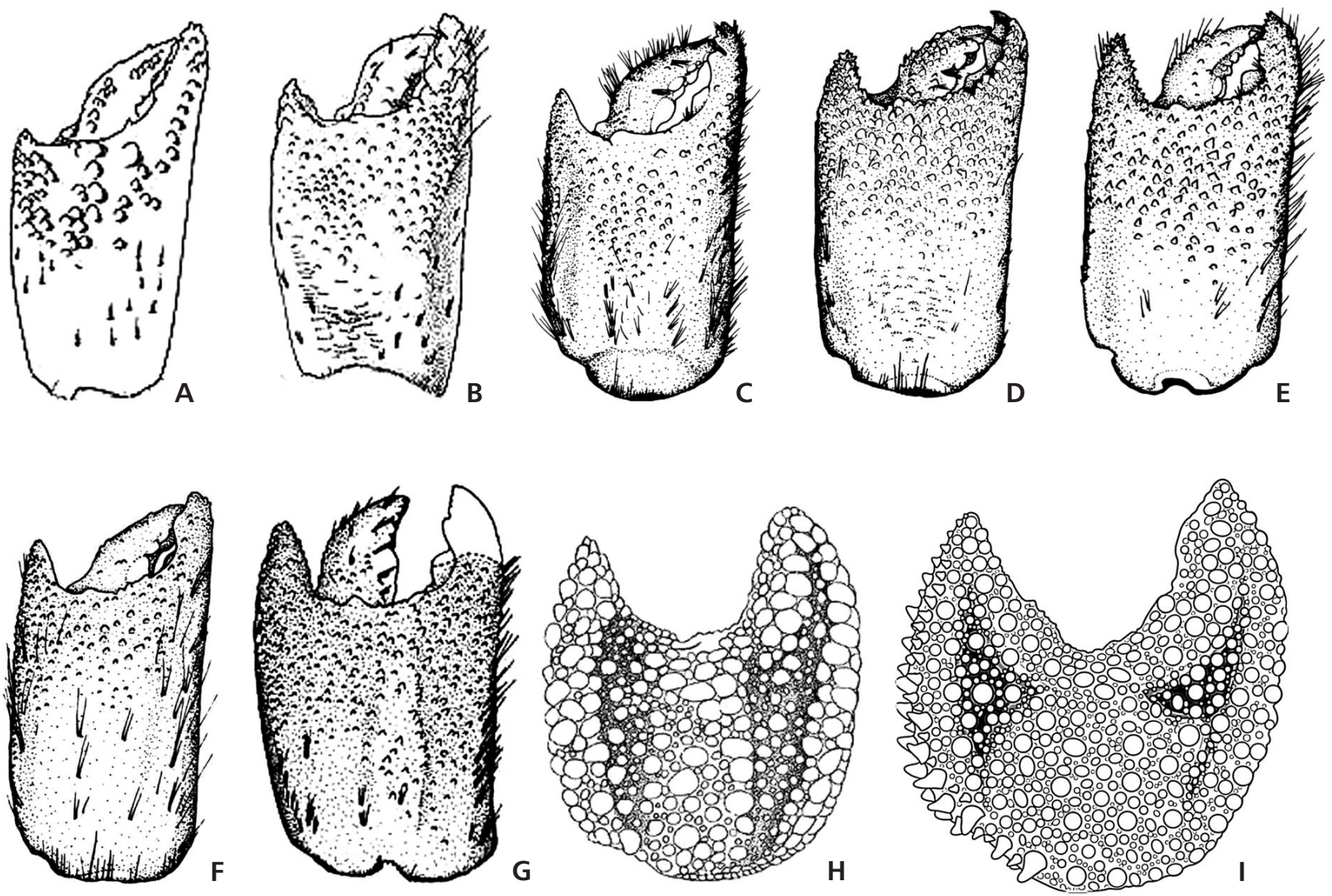

Figure 2. Comparison of right chelae of Xylopaguridae. • A - Prexylopagurus philippinensis (Forest, 1997). • B - P. caledonicus (Forest, 1997). $\bullet \mathrm{C}-$ P. anthonii (Lemaitre, 1995). $\bullet \mathrm{D}-$ Xylopagurus rectus A. Milne-Edwards, 1880 . $\bullet$ E - X. cancellarius Walton, $1950 . \bullet \mathrm{F}-$ X. tenuis Lemaitre, 1995. - G - X. tayrona Lemaitre \& Campos, 1993. • H - Lessinipagurus granulatus Beschin, De Angeli, Checchi \& Zarantonello, 2012. • I - L. vasjamikuzi sp. nov. Figures after: A, B - Forest (1997); C-F - Lemaitre (1995); G - Lemaitre \& Campos (1993); H - Beschin et al. (2012).

(Fig. 3A-G). Fossil parapylochelids all have a downpointed arrowhead shape of the gastric region within the posterior "arrow-tip" on either side a clear posterior gastric pit along with calcified posterior parts, and clear anterior branchial and massetic regions (see Fraaije et al. 2012, 2014; Fraaije 2014). The elongation and decalcification of the massetic regions and submassetic groove (i.e., the linea $\mathrm{d}$ in studies of extant hermit crabs) probably is an adaptation to inhabitation of long and narrow pieces of reed, bamboo and other comparable lodgings.

Interestingly, the calcified sixth abdominal tergite that was named Paguritergites yvonnecooleae by Fraaije et al. (2013) (Fig. 4H) co-occurs with numerous individuals of Parapylocheles michaeljacksoni and shows a morphology that is closely similar to the sixth abdominal tergites of species of Xylopagurus (Fig. 4A-J). This tergite probably constitutes the earliest record of this peculiar group of paguroids for which we propose a new family.

Based on the presence of a long decalcified submassetic groove the three extant species, Xylopagurus anthonii, X. philippinensis, and X. caledonicus are trans- ferred to the new genus, Prexylopagurus (Fig. 4A-C). Species of Xylopagurus lack a submassetic groove.

\section{Genus Prexylopagurus gen. nov.}

Type species. - Xylopagurus anthonii Lemaitre, 1995.

Other species. - Xylopagurus philippinensis Forest, 1997, and Xylopagurus caledonicus Forest, 1997.

Etymology. - The Latin prefix pre- alludes to the probably earlier evolutionary origin.

Diagnosis. - Shield distinctly longer (1.5 times) than wide, evenly convex. Dorsal surface glabrous except for a few scattered minute setal pits, and low rostral ridge. Rostrum subtriangular, exceeding subtriangular lateral projections. Elongated massetic and submassetic regions of similar size. Massetic region laterally decalicified. Submassetic groove anteriorly ending just lateral of lateral projection. 

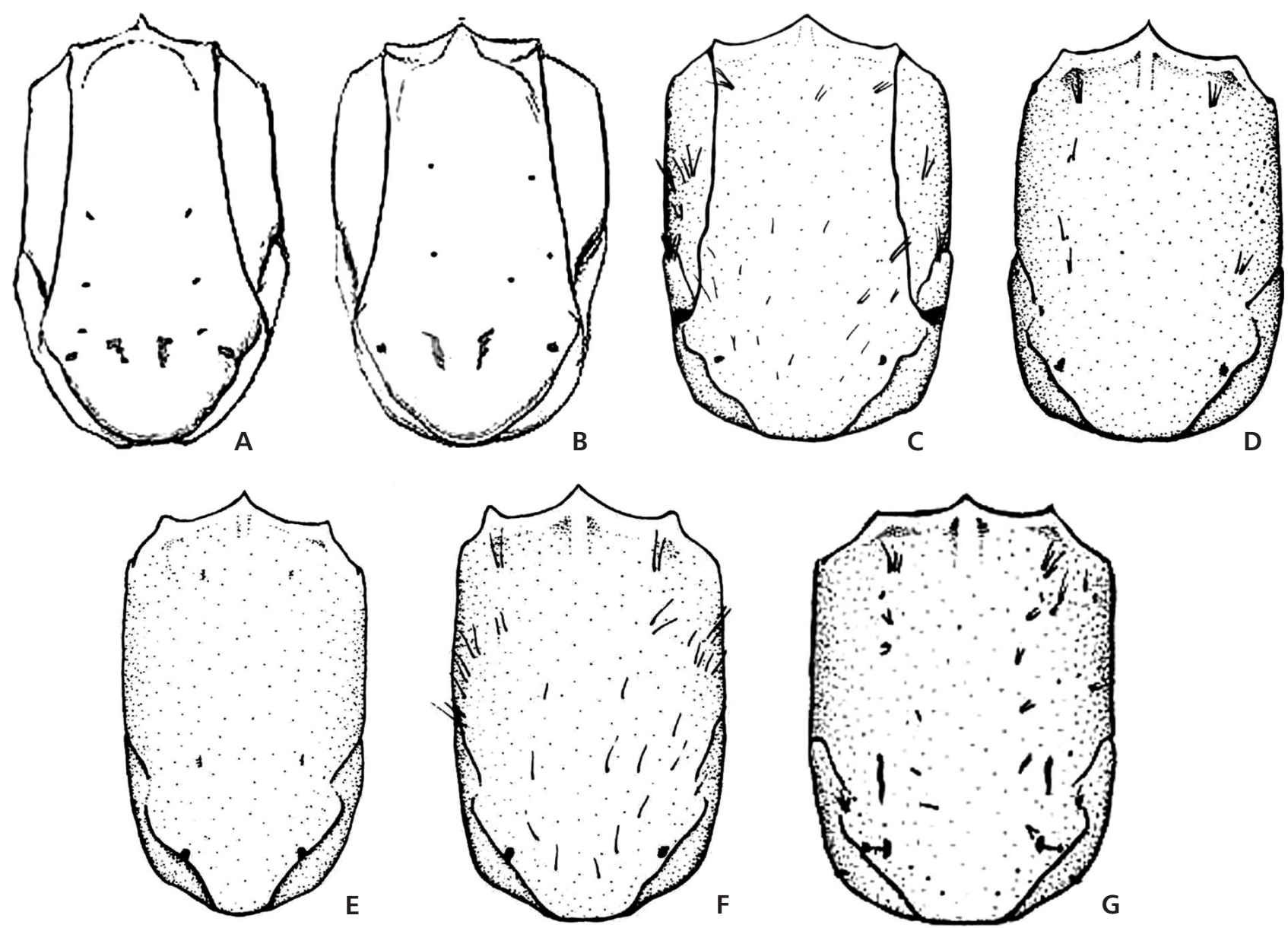

Figure 3. Comparison of thoracic shields. $\bullet$ A - Prexylopagurus philippinensis (Forest, 1997). $・$ B - P. caledonicus (Forest, 1997). $\bullet$ C - P. anthonii (Lemaitre, 1995). $\bullet \mathrm{D}-$ Xylopagurus rectus A. Milne-Edwards, $1880 \cdot \bullet \mathrm{E}-$ X. cancellarius Walton, $1950 . \bullet \mathrm{F}-$ X. tenuis Lemaitre, $1995 . \bullet \mathrm{G}-$ X. tayrona Lemaitre \& Campos, 1993. Figures after: A, B - Forest (1997); C-F - Lemaitre (1995); G - Lemaitre \& Campos (1993).

Gastric region shaped like an arrowhead pointing posteriorly with presence of gastric pits at about broadest part. Small keraial and anterior branchial regions.

Right cheliped strong, massive. Fingers each terminating in blunt calcareous claw. Dactylus with scattered, small spines and setal tufts on dorsal face, and row of setal tufts parallel to cutting edge; mesial margin with few tubercles and setal tufts. Fixed finger slightly overreaching dactylus. A "pseudo-fixed finger" extending parallel to the outer side of the dactylus gives the cheliped a typical gouge-like morphology; dorsal face with small spines or tubercles proximally; dorsolateral margin with row of small spines. Left cheliped slender, short, reaching to distal margin of carpus of right cheliped. Fingers distinctly longer than palm, terminating in corneous claw, opposing faces of fingers concave; cutting edge of fixed finger with closely spaced, minute corneous teeth; cutting edge of dactylus with row of minute, fused corneous teeth; dorsal and ventral surfaces with numerous setal tufts. Operculate tergite of sixth abdominal somite with raised crenulate margins bearing evenly spaced tufts of long setae. Dorsal surface divided into four equal or subequal quadrants by anterior and posterior longitudinal median grooves and a median or submedian transverse depression.

Remarks. - This new genus can be distinguished immediately from Xylopagurus by the presence of decalcified submassetic grooves (linea d) on the shield and a decalcification of the lateral half of the massetic region. Morphologically, the shield of species of Prexylopagurus gen. nov. is in between that of a parapylochelid and of $X y$ lopagurus. Within this lineage, there is an increase in the degree of decalcification of the massetic region.

Prexylopagurus anthonii (Lemaitre, 1995) comb. nov. Figures 2C, 3C, 4C

1995 Xylopagurus anthonii Lemaitre, 1995, p. 14, figs $7 \mathrm{~d}, 11-13$. 
Original description. - The detailed description of several individuals of this species provided by Lemaitre (1995) need not be repeated here.

Remarks. - Prexylopagurus anthonii can be differentiated from its congeners by the possession of a straight postfrontal ridge; the sixth abdominal tergite is more evenly and regularly covered with rounded pits and tubercles.

Prexylopagurus philippinensis (Forest, 1997) comb. nov. Figures 2A, 3A, 4A

1997 Xylopagurus philippinensis Forest, 1997, p. 422, figs $1-3,4 \mathrm{a}$.

Original description. - The detailed description of several individuals of this species given by Forest (1997) need not be repeated here.

Remarks. - Prexylopagurus philippinensis differs from congeners in having a markedly spinose rostrum and a subcircular postfrontal ridge; a very small "pseudo-fixed finger" and coarse ornamentation on the anterior part of the outer side of the right cheliped; the sixth abdominal tergite is more quadratic in outline than that of $P$. anthonii and less elongated than that of $P$. caledonicus.

Prexylopagurus caledonicus (Forest, 1997) comb. nov. Figures 2B, 3B, 4B

1997 Xylopagurus caledonicus Forest, 1997, p. 427, figs $4 \mathrm{~b}, 5,6$.

Original description. - The detailed description of several individuals of this species presented by Forest (1997) need not be repeated here.

Remarks. - Prexylopagurus caledonicus is differentiated from congeners in having an oblique furrow that extends from the lateral side of the lateral projections towards the flanks of the curved postfrontal ridge.

\section{Genus Lessinipagurus Beschin, De Angeli, Checchi \& Zarantonello, 2012}

Type species. - Lessinipagurus granulatus Beschin, De Angeli, Checchi \& Zarantonello, 2012, by original designation.

Emended diagnosis. - Propodus with palm taller than long and a slightly inclined carpus-propodus articulation; palm subsquarish to circular in outline; curved, divergent, upper and lower margins with convex profile; upper margin with two rows of large, forwardly directed tubercles lined up among smaller tubercles, and with prominent protuberance at mesial dorsodistal angle; tuberculated outer surface with two longitudinal depressions; convex inner surface, with small tubercles on the median part and larger tubercles on the lower and upper part; fixed finger shorter than palm, with several small rounded teeth on distal end of occlusal margin.

\section{Lessinipagurus vasjamikuzi sp. nov.} Figures 5A, B, 6A-D

Holotype. - Holotype, and sole specimen known to date, is RGA/SMNH 1987. It is a well-preserved right cheliped, measuring 21.5, 18.5, and $6.0 \mathrm{~mm}$ in length, height, and width, respectively.

Type horizon and locality. - Outcrop (45 $15^{\circ} 12^{\prime} 48.5^{\prime \prime} \mathrm{N}$, $14^{\circ} 00^{\prime} 33.0^{\prime \prime} \mathrm{E}$ ) near Gračišće (Istria, Croatia), along the main road from Pazin to Labin; upper Eocene (upper Bartonian-lower Priabonian) olistostrome breccia horizon.

Etymology. - The specific epithet honours the Slovenian palaeontologist, Dr. Vasja Mikuž, in recognition of his considerable contributions to the palaeontological record of Slovenia and Istria.

Diagnosis. - Propodus with palm significantly taller than long; palm oval to ellipsoid in outline; curved, divergent, upper and lower margins with convex profile; upper margin with two rows of large, forwardly directed tubercles, ending in prominent, convexly diverging spiniform dorsomesial projection; tuberculated outer surface with two triangular longitudinal depressions; convex inner surface, with small flat tubercles; fixed finger almost as long as palm, with two larger, rounded teeth medially and four small rounded teeth on distal end of occlusal margin.

Description. - Right cheliped with ellipsoid oval outline, semi-circular in cross section; flat outer side and convex inner side, of large dimensions for the genus. Palm significantly taller than long, with inclined propodus/dactylus articulation, dorsal and ventral margins convex. Dorsal margin adorned with two rows of alternating, large, forwardly directed, spine-like, tubercles; one row positioned on the inner side, the other on the outer. Dorsal margin of cheliped ending in prominent, convexly diverging spiniform dorsomesial projection distally, protruding almost as far as fixed finger on the ventral margin, contributing to the ellipsoid oval appearance of the right cheliped (Fig. 5A, B). 

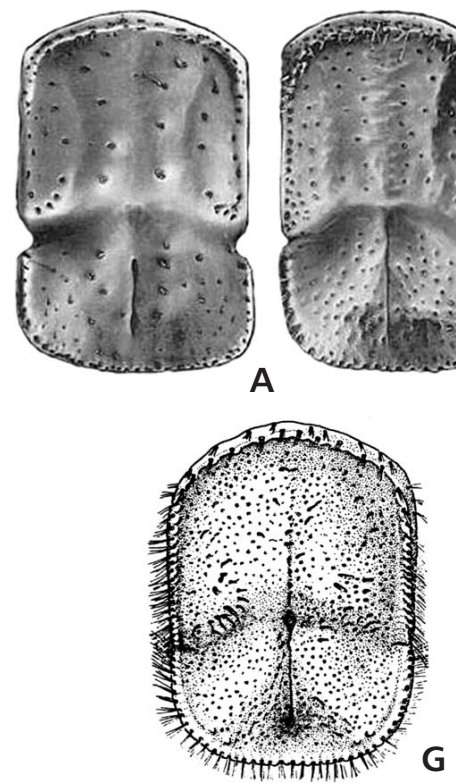

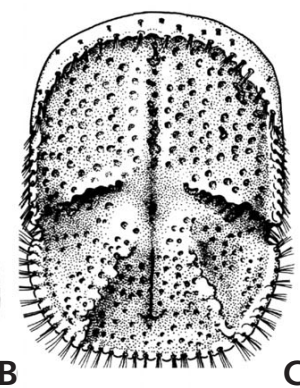

B

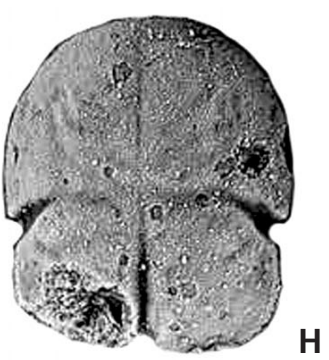

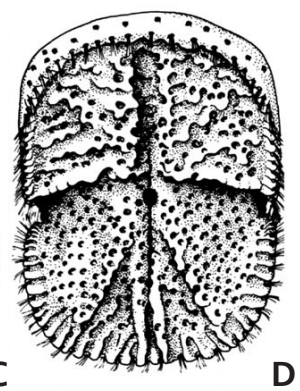
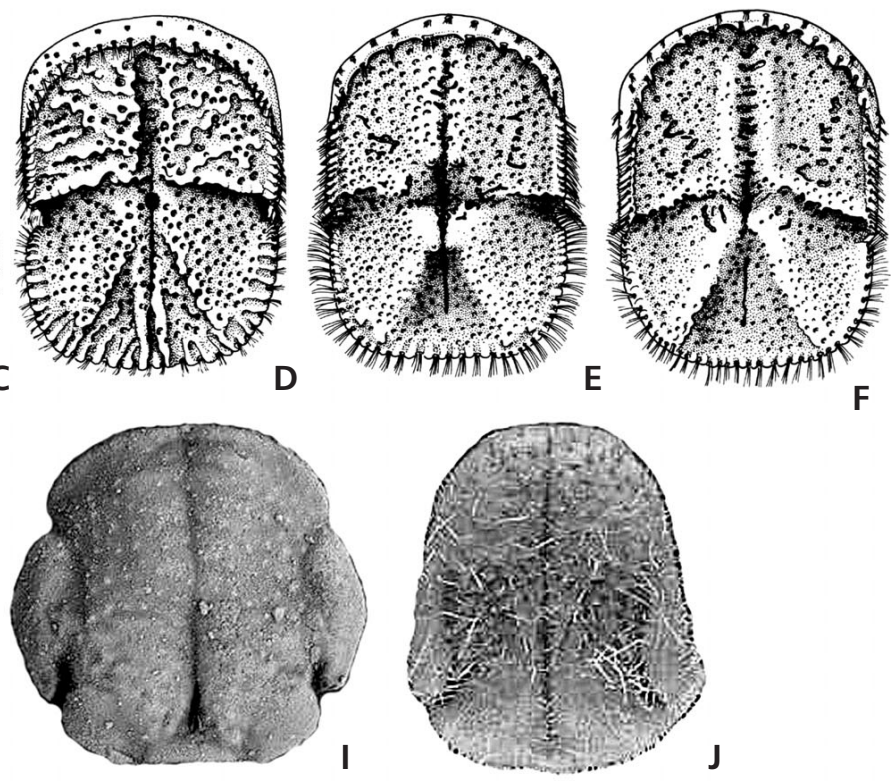

$\mathbf{F}$

Figure 4. Comparison of sixth abdominal tergites. • A - Prexylopagurus philippinensis (Forest, 1997). • B - P. caledonicus (Forest, 1997) $\bullet$ C - P. anthonii (Lemaitre, 1995). $\bullet$ D - Xylopagurus rectus A. Milne-Edwards, 1880. $\bullet$ E - X. cancellarius Walton, $1950 . \bullet$ F - X. tenuis Lemaitre, 1995. - G - X. tayrona Lemaitre \& Campos, 1993. - H - Paguritergites yvonnecooleae Fraaije, Artal, Van Bakel, Jagt \& Klompmaker, 2013. -I - Parapylochelitergites pustulosus Fraaije, Artal, Van Bakel, Jagt \& Klompmaker, 2013. • J - Parapylocheles scorpio (Alcock, 1894). Figures after: A, B - Forest (1997); C-F - Lemaitre (1995); G - Lemaitre \& Campos (1993); H-J - Fraaije et al. (2013).
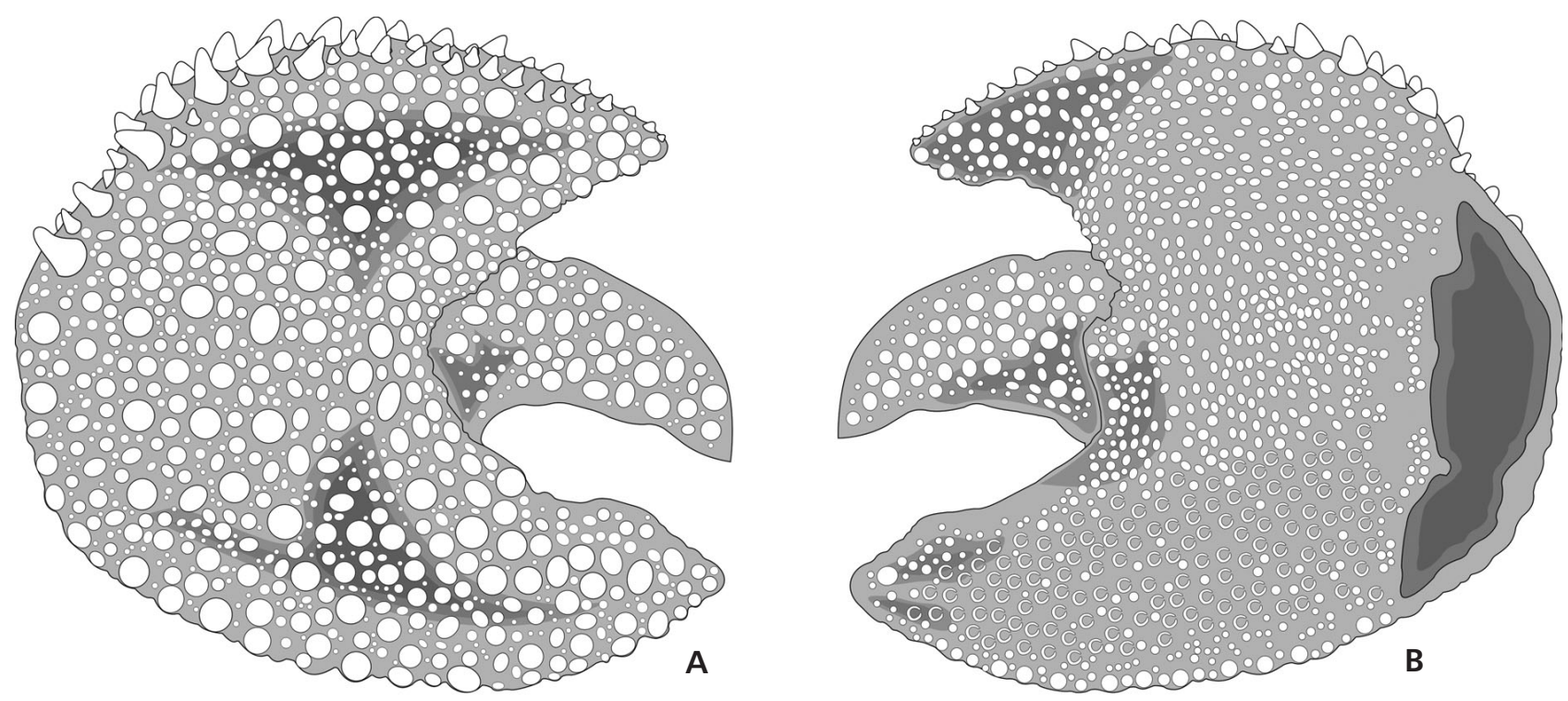

Figure 5. Reconstruction of the right chela of Lessinipagurus vasjamikuzi sp. nov. $\bullet$ A - outer side. $\bullet$ B - inner side of chela.

Ventral margin adorned with large rounded tubercles, interspersed with small tubercles. Fixed finger almost as long as palm, triangular, robust, convexly curved, ventral margin ornamented in similar fashion to palm, with alternating larger and smaller tubercles. Occlusal margin of fixed finger wide, hollowly concave at articulation rim, narrowing distally to a medially positioned two round teeth, distal part of cutting edge ending in four smaller rounded teeth, flattened and straight distal end, slightly inclined to the inner side. Outer surface of right cheliped densely tuberculate. Large raised, round tubercles repeatedly alternating with smaller tubercles (Fig. 6A), more dense toward cheliped margins and along fixed finger length. Two elongated triangular depressions extending parallel to dorsal and ventral margins, continuing along fixed finger and dorsomesial projection. Outer surface 


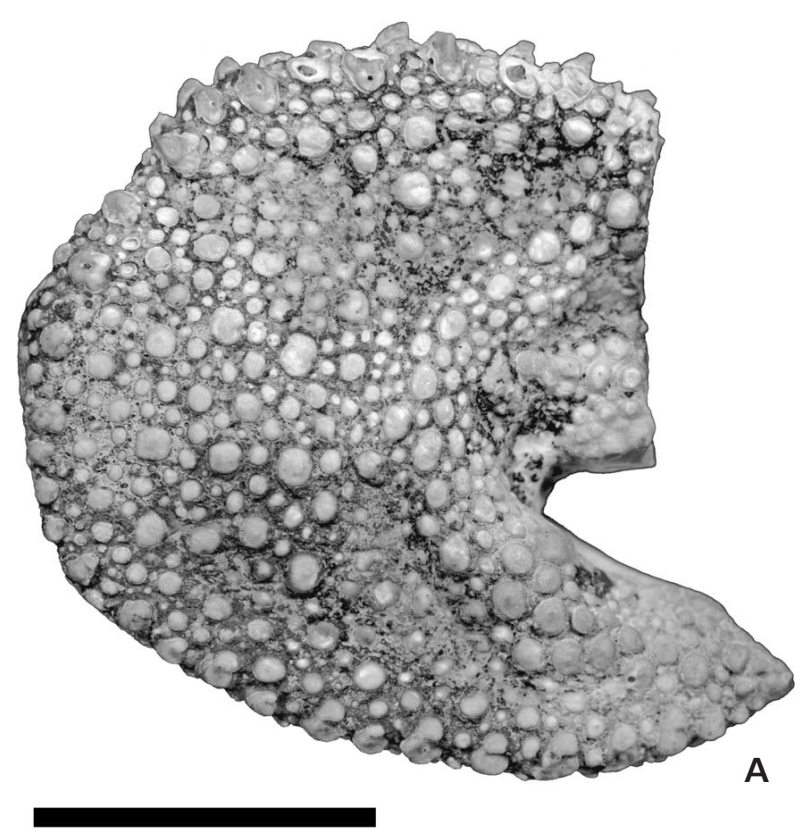

A

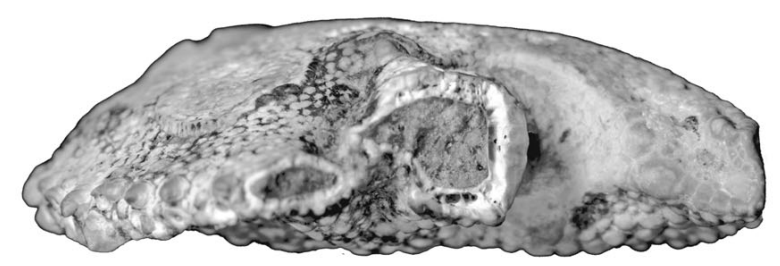

C
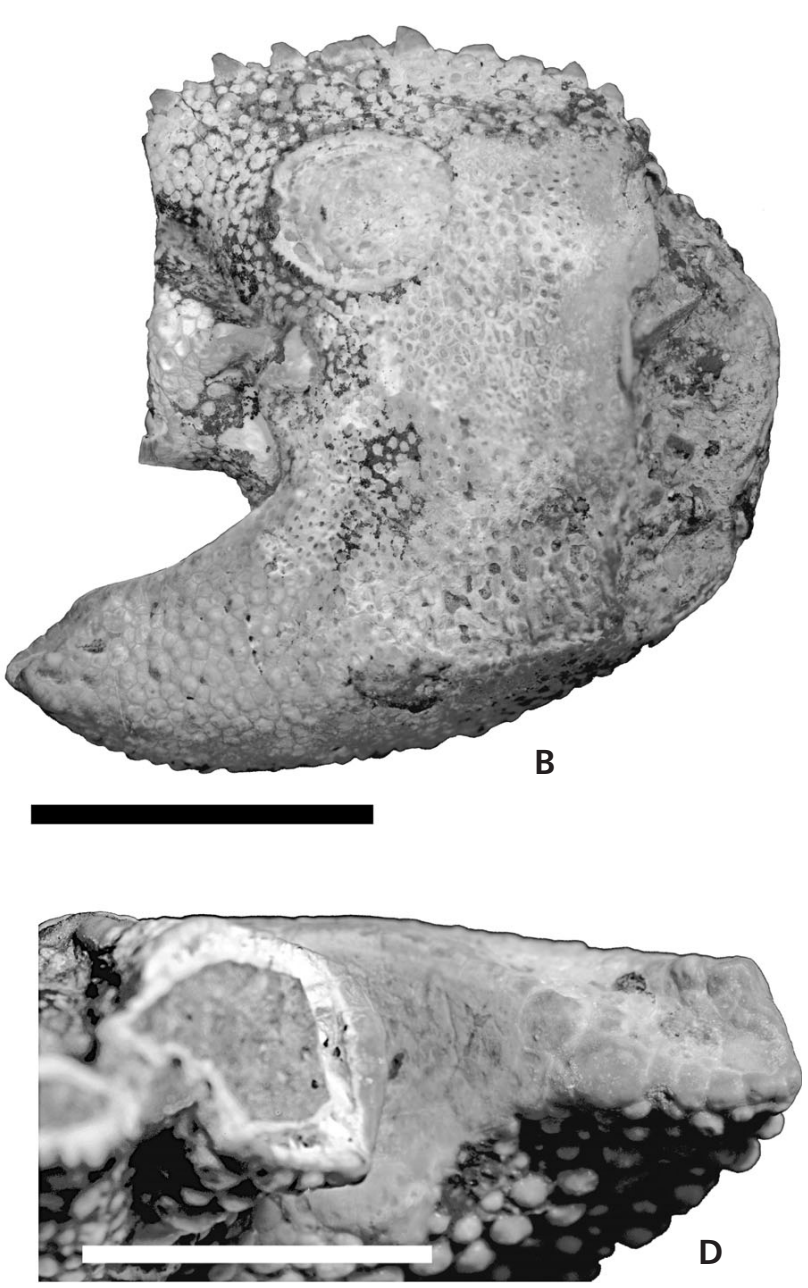

Figure 6. Lessinipagurus vasjamikuzi sp. nov. (holotype, RGA/SMNH 1987). • A - outer side. • B - inner side. • C - cross-section of dactylus. - D - close-up of occlusal margin. Scale bars: A-C = $10 \mathrm{~mm} ; \mathrm{D}=5 \mathrm{~mm}$.

margins rounded, margin along propodus/dactylus articulation swollen, inflated central palm area separating two triangular depressions. Inner surface of cheliped covered with small, flat, oval tubercles, sharply demarcated only on distal end and showing a pattern of imbrication, larger, rounded tubercles along ventral and dorsal inner margins (Fig. 6B). Dactylus only partially preserved, appearing stout, subsquarish in cross section (Fig. 6C), proximal part of occlusal margin forming a smooth molar-like tooth to fit in hollow of fixed finger, outer surface decorated with large round tubercles, inner surface with smaller, but distinct round tubercles (Fig. 6D).

Remarks. - This new form is assigned to Lessinipagurus on the basis of all morphological features as listed by Beschin et al. (2012). These include the circular outline of the tuberculated cheliped, with a palm that is taller than long and especially the prominent, spiniform dorsomesial projection on the distal dorsal margin.

In overall cheliped shape and ornamentation,
Lessinipagurus vasjamikuzi sp. nov. most closely resembles the type species, L. granulatus, but it can be differentiated from the latter by a unique set of characters. The greater size stands out, as the cheliped of the new species is significantly larger than individuals of L. granulatus (Table 1). The greater size might reflect different ontogenetic stages, but palm proportions demonstrate that, with a comparable palm length, palm height is approximately 1.35 times greater in the new species. In addition, the palm is much shorter in comparison to total propodus length, so that the cheliped in L. vasjamikuzi sp. nov. has a rounder ellipsoid outline. The fixed finger is wider proximally and triangular in shape, contrary to L. granulatus, rendering a $\mathrm{V}$-shaped angle between the fingers rather than a U-shaped one as in L. granulatus. The two longitudinal depressions on the outer surface are less pronounced and triangular. The ornamentation of tubercles also differs slightly; on the outer surface, tubercles are evenly mixed: large round ones amidst an equal density of smaller tubercles, and more spaced than in the Italian material. The two rows of tuber- 

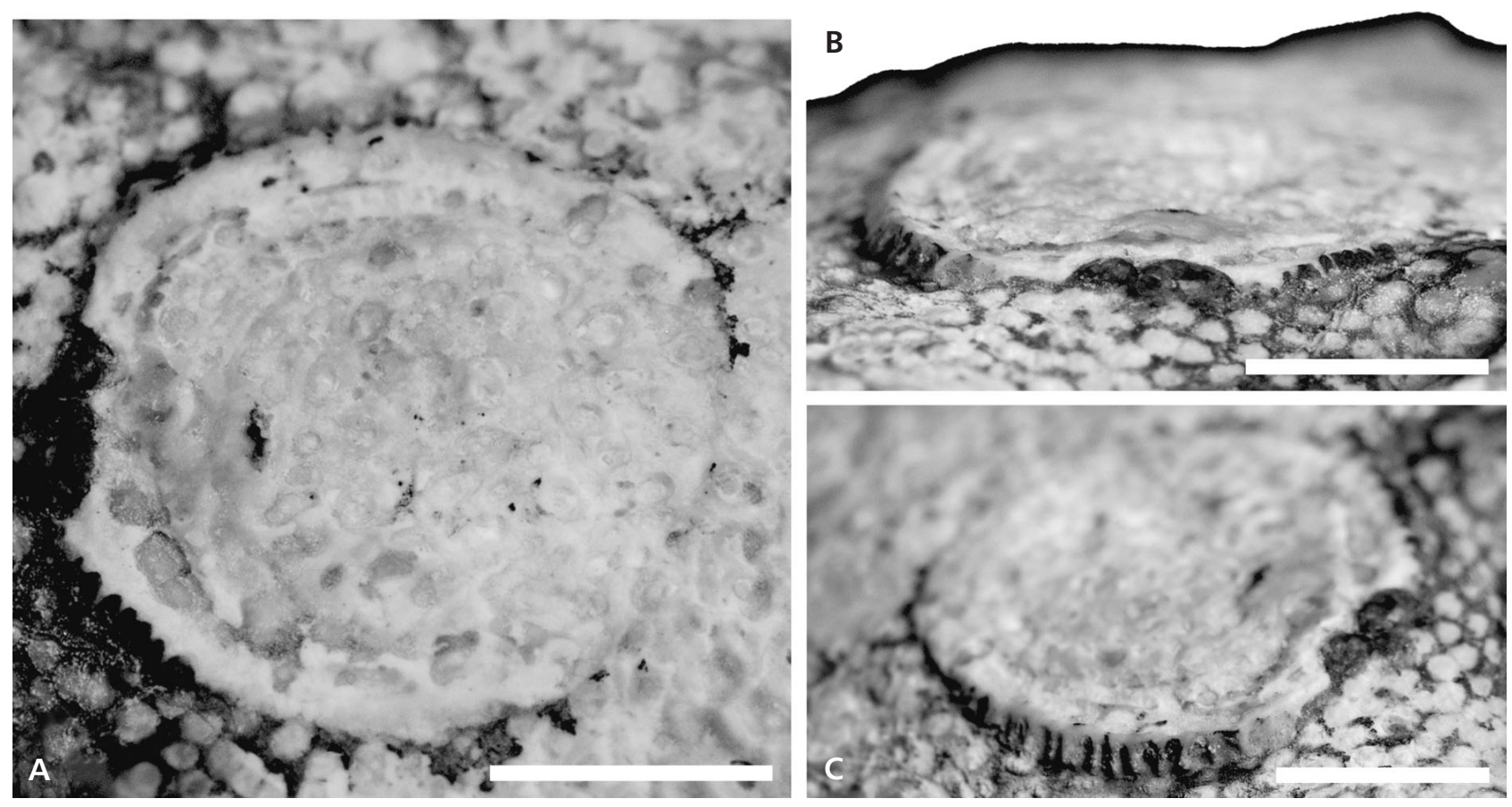

Figure 7. Close-up of epibiont attachment scar on Lessinipagurus vasjamikuzi sp. nov. (holotype, RGA/SMNH 1987). All scale bars $=2 \mathrm{~mm}$.

Table 1. Morphometric comparison of Lessinipagurus granulatus Beschin, De Angeli, Checchi \& Zarantonello, 2012 and Lessinipagurus vasjamikuzi sp. nov.

\begin{tabular}{|l|l|c|c|c|c|c|c|}
\hline \multicolumn{1}{|c|}{ Species } & \multicolumn{1}{|c|}{ Specimen No. } & $\begin{array}{c}\text { Propodus } \\
\text { length (in mm) }\end{array}$ & $\begin{array}{c}\text { Palm length } \\
\text { (in mm) }\end{array}$ & $\begin{array}{c}\text { Palm height } \\
\text { (in mm) }\end{array}$ & $\begin{array}{c}\text { Palm width } \\
\text { (in mm) }\end{array}$ & Locality & Age \\
\hline Lessinipagurus granulatus & MCZ 2732 (holotype) & 14.9 & 11.2 & 12.9 & 6.1 & Grola, Vicenza, Italy & middle Eocene, Lutetian \\
\hline Lessinipagurus granulatus & MCZ 3109 & 10.0 & 8.0 & 8.7 & 4.4 & Grola, Vicenza, Italy & middle Eocene, Lutetian \\
\hline Lessinipagurus granulatus & MCZ 3044 & 13.0 & 9.0 & 11.6 & na & Parona, Vicenza, Italy & late Eocene, Priabonian \\
\hline Lessinipagurus gramulatus & AO C-477/1 & 11.0 & 8.5 & 9.5 & 4.0 & Arzignano, Vicenza, Italy & middle Eocene, Lutetian \\
\hline Lessinipagurus vasjamikuzi sp. nov. & RGA/SMNH 1987 & 21.5 & 11.7 & 18.3 & 6.0 & Gračišce, Istria, Croatia & late Bartonian-early Priabonian \\
\hline
\end{tabular}

cles on the dorsal margin are forwardly oriented and spine like in the Istrian specimen.

On the lateral proximal side, the propodus described shows remains of what appears to have been a balanomorph association (Fig. 6B). Indeed, the surface of the propodus reveals a tiny discoid structure that corresponds to an attachment scar.

Infraclass Cirripedia Burmeister, 1834

Superorder Thoracica Darwin, 1854

Order Sessilia Lamarck, 1818

Infraorder Balanomorpha Pilsbry, 1916

Figures 7A-C

Description. - The present regularly discoid scar is about $4.5 \mathrm{~mm}$ in diameter corresponds to a flat calcareous disc that displays concentric rings at some of its marginal points (Fig. 7A). These rings show very thin radial striations pointing toward the centre of the scar. At some points, the scar reveals remains of a marginal wall in the form of paired striae (Fig. 7B, C). The central part of the scar appears to have been filled by a calcareous plug and does not reveal typical structures. Of note is a clear deformation of palm tubercles that underlie the scar (Fig. 7A).

Taxonomical remarks. - The concentric and thinner radial striations visible at the scar margin are typical of a balanomorph basal plate. The central aspect of this plate is here hidden by a calcareous layer. The remaining three-dimensional parts of the scar display the ornamentation of a balanomorph wall plate. The discoid shape of the scar is more or less typical of balanomorphs that grow in isolation on substrates. The specific nature of the balanomorph involved cannot be identified on the basal plate alone.

Taphonomical remarks. - The post-mortem or syn-vivo nature of the present association is difficult to determine on the basis of taphonomic aspects. However, although 
recovered in isolation, the present propodus retains its articulation, which is indicative of a relatively brief interval of exposure of the hermit crab carcass prior to final burial. Indeed, this specific articulation site in decapod crustaceans is of pre-burial dislocation, i.e., one of the first to become dislodged from the rest of the body (Briggs \& Kear 1994, Locatelli 2012). This brief pre-burial exposure of the carcass would probably not have allowed postmortem settlement and growth of a balanomorph of such dimension (4.5 mm).

However, the flattening of the tubercles appear to correspond to hindrance during the production of superficial cuticular layers (as already postulated in the case of ectosymbiotic bacterial colonies; see Robin et al. 2015) rather than to true abrasion of the tubercles that could have occurred as a result of post-mortem epibiont attachment. This would hardly be observed in a post-mortem association, but would more reliably be the result of a syn-vivo association with the anomuran. The average growth of balanomorphs is difficult to assess in detail, but in general varies from 10 to $160 \mu \mathrm{m}$ per day, depending of growth stage and environment (Crisp \& Bourget 1985). In this respect, a mean growth rate of 50 to $70 \mu \mathrm{m}$ per day seems to be a convenient assessment of a classic adult balanomorph. This implies that such an association took place during the intermoult period of the host, demanding an average of about three months to reach such a size. This matches the intermolt duration of a subadult/adult anomuran of normal size. Indeed, studies on extant large-sized anomurans (Lithodidae; carapace length $<80 \mathrm{~mm}$ ) have revealed that their intermoult duration may reach up to 13 months (Lovrich et al. 2003).

Remarks on partner encounter. - The genus Lessinipagurus is here shown to be related to extant Xylopagurus, which live in hollowed-out wooden structures and occupied gastropod shells. The perfectly round (of an estimated age of $c a 80$ days) growth of the balanomorph appears to have been possible because it was not affected by the chela rubbing against the inside the pagurid shelter (woody structure or other type). In their abodes, extant Xylopagurus often reveal extremities of their pereiopods exposed outside of the wood shelter (Fig. 8A, B). This particular habit may have permitted the syn-vivo attachment and subsequent growth of the balanomorph on this (sub)adult Lessinipagurus during its intermolt period.

Contrary to what might be expected, records of balanomorph barnacles as epibionts of extinct decapod crustaceans are scarce. Cases recorded in the literature invariably correspond to indeterminate balanomorphs on crabs of the families Majidae (Glaessner 1960), Mathildellidae (Feldmann 2003), Atelecyclidae (Waugh et al. 2004) and Cancridae (Feldmann et al. 2006). All of these cases correspond to associations of Miocene age, which means that the present case is the earliest report of similar barnacles attached on a decapod crustacean, of more or less comparable age to two balanomorph basal plates on the propodus of an Eocene (Ypresian) Hoploparia gammaroides (M'Coy, 1849) from the London Clay (NHMUK In.35300; see Robin 2015). However, the exact nature (either post-mortem or syn-vivo) of the latter has not been studied; the present example documents effective ectosymbiosis.

The present association may be related to the profusion of balanomorph larvae in the environment occupied by Lessinipagurus or to the assumedly muddy marine bottom of this setting, in which sunken wood fragments (and occasionally their occupants) provided suitable substrates for barnacle attachment and growth. Each sunken piece of driftwood may thus have corresponded to a local microenvironment (Hoyoux 2010) involving assemblages of decapod and thoracican barnacles.

\section{Ecology}

All extant xylopagurids known to date are found living in hollow pieces of reeds like bamboo, in open-ended cylindrical cavities (pieces of driftwood) or in empty polychaete tubes (Lemaitre 1995, Forest 1997). Xylopagurus rectus A. Milne-Edwards, 1880, X. tayrona Lemaitre \& Campos, 1993, Prexylopagurus anthonii (Lemaitre, 1995) and X. tenuis Lemaitre, 1995 occur in the western Atlantic, while X. cancellarius Walton, 1950 inhabits the eastern Pacific. From the Indo-West Pacific P. philippinensis (Forest, 1997) and P. caledonicus (Forest, 1997) have been described. These species occur at depths ranging from several metres (X. cancellarius) to several hundreds of metres. Preyxlopagurus caledonicus was dredged from a depth of 591 metres (Forest 1997).

Interestingly, the recently discovered bloom of Lessinipagurus (De Angeli 2016, in prep.) in the upper Eocene of northern Italy parallels the origin and evolution and subsequent ecological expansion of especially reed and bamboo (Poaceae) (e.g., Strömberg 2011, Poinar \& Columbus 2013, Wang et al. 2013).

There is a characteristic type of "pseudo-fixed" finger at the dorsal margin of the cheliped. The gouge-like morphology of the right cheliped with "pseudo-fixed" finger, dactylus and palm all covered with coarse, close-set spines and tubercles looks like a good rasping and stabbing tool to enlarge and smooth the inner side of hollow plants or other organic remains.

As a result of the elongation and decalcification of the massetic region and submassetic groove, these paguroid carapaces became more flexible so as to inhabit long and narrow pieces of reed, bamboo and other comparable lodgings. 

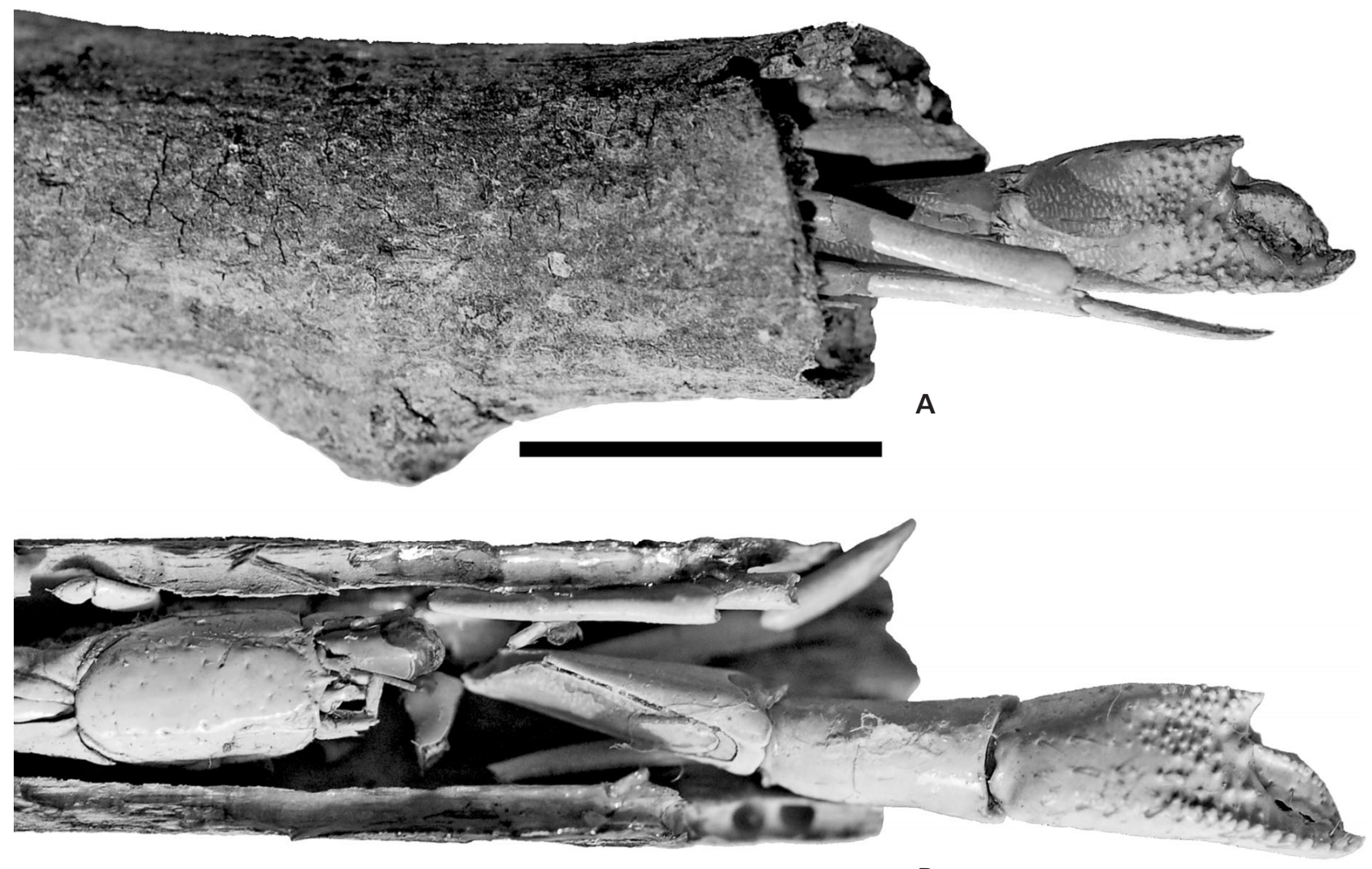
B

Figure 8. Extant Prexylopagurus philippinensis (Forest, 1997), specimen MAB k03567, Olango Island, Cebu, Philippines, inhabiting a hollowed sunken wood. $\bullet$ A - lateral view of exposed chelae. $\bullet \mathrm{B}-$ dorsal view with the removed woody shelter. Both scale bars $=10 \mathrm{~mm}$.

\section{Palaeobiogeography}

The newly erected family Xylopaguridae appears to have originated in the Tethyan Realm, perhaps as early as the Jurassic, and displays a Tethyan distribution throughout the Cenozoic. The distribution pattern of extant species of Xylopagurus, in the Indian Ocean and West Pacific on the one hand, and the Pacific and West Atlantic on the other, confirms the Tethyan origination and distribution (Forest 1997). Not unlike galatheoids (De Angeli \& Garassino 2003), this taxon underwent rapid diversification and speciation in the Tethyan Ocean during the Eocene (De Angeli 2016, in prep.), possibly followed by another diversification in the Indo-Pacific region after the closure of Tethyan seaways (Renema 2007, Macpherson et al. 2010). This eastward shift of biodiversity is observed also in other marine organisms such as molluscs, fish, and mangroves, and indicates that tectonic changes are important drivers of modern biodiversity (Renema et al. 2008).

\section{Conclusions}

The first record of an Eocene paguroid, Lessinipagurus vasjamikuzi sp. nov., provides an opportunity to revise the diversity of the genus and refine the phylogeny of the Paguroidea. This unique genus, up to now known exclusively from a single species from the Eocene of Italy, shows a wider palaeogeographical range and a higher diversity in the Tethyan Ocean during the Eocene than previously thought.

The type specimen of Lessinipagurus vasjamikuzi sp. nov. also reveals the remains of a syn-vivo balanomorph epibiotic association, which is the earliest record of such and the first to be described from an extinct anomuran. This interesting association most likely resulted from specific ecological conditions, where sunken pieces of wood and their occupants provided the only suitable substrate on a deep-water muddy sea floor.

We erect a new family, Xylopaguridae, on the basis of a distinctive set of characters of the dorsal carapace, chelae, and operculate tergite of the sixth abdominal somite. A new genus, Prexylopagurus, within this family, now accommodates three extant species, namely $P$. anthonii, $P$. philippinensis and $P$. caledonicus.

The new family appears to have originated in the Tethyan Realm, perhaps as early as the Jurassic. Increased speciation within the genus Lessinipagurus during the late Eocene parallels the evolution and ecological expansion of 
grasses, especially reed and bamboo. As Lessinipagurus exclusively inhabited wood and bamboo fragments, this represents a rare example of coevolution between land plants and marine organisms.

\section{Acknowledgements}

We wish to thank Rafael Lemaitre for valuable information on extant paguroid carapace morphology; Barry van Bakel for assistance in obtaining comparative extant material of Xylopagurus; Àlex Ossó for access to additional Lessinipagurus material; Vlasta Ćosović, Vasja Mikuž and Matija Križnar for assistance in interpreting the stratigraphy of Eocene beds in Istria; John W.M. Jagt for linguistic checking and insightful comments and Andreja Žibrat Gašparič for proofreading of the manuscript. We are especially grateful to Rodney M. Feldmann (Kent State University at Stark, Department of Geology, USA) and Matúš Hyžný (Comenius University, Faculty of Natural Sciences, Department of Geology and Palaeontology) for their careful reviews and constructive suggestions.

\section{References}

AlCOCK, A. 1894. Natural history notes from H.M. Royal Indian Marine Survey Steamer 'Investigator', commander R.F. Hoskin, R.N., commanding; Series II, No. 1. On the results of deep-sea dredging during the season of 1890-91 (continued). Annals and Magazine of Natural History 6(13), 321-334. DOI 10.1080/00222939408677707

BABIĆ, L. \& ZuPANIČ, J. 1996. Coastal Dinaric flysch belt: paleotransport model for the Pazin Basin, and the role of a foreland uplift. Natura Croatica 5, 317-327.

BACHMAYer, F. \& Nosan, A. 1959. Ein bemerkenswerter Crustaceenfund aus Gračišče bei Kubed (Nordistrien). Geologija 5, 80-85.

Beschin, C., Busulini, A. \& Tessier, G. 2010. Crostacei decapodi dell'Eocene medio (Bartoniano) di Soave (Verona - Italia settentrionale). Studi e Ricerche - Associazione Amici del Museo "G. Zannato”, Montecchio Maggiore (Vicenza) 17, 11-28.

Beschin, C., De Angeli, A., Checchi, A. \& Zarantonello, G. 2012. Crostacei del giacimento eocenico di Grola presso Spagnago di Cornedo Vicentino (Vicenza, Italia Settentrionale) (Decapoda, Stomapoda, Isopoda). 99 pp. Museo di Archeologia e Scienze Naturali "G. Zannato", Montecchio Maggiore, Vicenza.

BItTNER, A. 1880. Beiträge zur Kenntniss alttertiärer Echinidenfaunen der Südalpen. I. Echinidenfauna des istro-dalmatinischen Eocaens. Beiträge zur Paläontologie Österreich-Ungarns und des Orients 1, 43-71.

Bramlette, M.N. \& Sullivan, F.R. 1961. Coccolithophorids and related nannoplankton of the Early Tertiary in California. Micropaleontology 7, 129-188. DOI 10.2307/1484276

Bramlette, M.N. \& WiLcoxon, J.A. 1967. Middle Tertiary calcareous nannoplankton of the Cipero section, Trinidad. W.I. Tulane Studies in Geology and Paleontology 5, 93-131.
Briggs, D.E.G. \& Kear, A.J. 1994. Decay and mineralization of shrimps. Palaios 9, 431-56. DOI 10.2307/3515135

Bukry, D. 1971. Cenozoic calcareous nannofossils from the Pacific Ocean. San Diego Society of Natural History, Transactions 16, 303-327.

BurmeIster, H.I. 1834. Beiträge zur Naturgeschichte der Rankenfüsser (Cirripedia). 59 pp. G. Reimer, Berlin.

Busulini, A., Beschin, C. \& Tessier, G. 2012. Nuovo contributo alla conoscenza dei crostacei decapodi della marna di Possagno (Eocene superiore - Italia settentrionale). Lavori Società veneziana di Scienze naturali 37, 43-72.

Crisp, D.J. \& Bourget, E. 1985. Growth in barnacles, 199-244. In Blaxter, J.H.S., Russel, F.S. \& Yonge, M. (eds) Advances in Marine Biology 22. Academic Press, London.

Ćosović, V., Drobne, K. \& Moro, A. 2004. Paleoenvironmental model for Eocene foraminiferal limestones of the Adriatic carbonate platform (Istrian peninsula). Facies 50, 61-75. DOI 10.1007/s10347-004-0006-9

DARWIN, C. 1854. A monograph on the sub-class Cirripedia with figures of all species. 684 pp. The Ray Society, London.

De Angeli, A. 2016. New Middle Eocene Hermit Crabs from "Main" Quarry at Vicenza (NE Italy), 21-22. In CHARBonNIER, S. \& Picot, L. (eds) $6^{\text {th }}$ Symposium on Mesozoic and Cenozoic decapod crustaceans: Villers-Sur-Mer, France, Abstracts. Muséum National d'Histoire Naturelle, Paris.

De Angeli, A. \& Garassino, A. 2003. Galatheids, chirostylids and porcellanids (Crustacea, Decapoda, Anomura) from the Eocene and Oligocene of Vicenza (northern Italy). Contributions to Zoology 72(2-3), 97-100.

FABIANI, R. 1910. I crostacei terziari del Vicentino. Bolletin Museo Civico Vicenza 1, 1-40.

Feldmann, R.M. 2003. The Decapoda: new initiatives and novel approaches. Journal of Paleontology 77, 1021-1039. DOI 10.1666/0022-3360(2003)077<1021:TDNIAN>2.0.CO;2

Feldmann, R.M., Schweitzer, C.E. \& McLauchlan, D. 2006. Additions to the records for decapod Crustacea from Motunau and Glenafric beaches, North Canterbury, New Zealand. New Zealand Journal of Geology and Geophysics 49, 417-427. DOI 10.1080/00288306.2006.9515178

Forest, J. 1997. Présence du genre Xylopagurus A. Milne-Edwards, 1880 (Crustacea, Decapoda, Paguridae) dans 1'Indo-Ouest Pacifique, avec la description de deux espèces nouvelles. Zoosystema 19, 421-435.

FraAiJe, R.H.B. 2014. Diverse Late Jurassic anomuran assemblages from the Swabian Alb and evolutionary history of paguroids based on carapace morphology. Neues Jahrbuch für Geologie und Paläontologie, Abhandlungen 273, 121-145. DOI 10.1127/0077-7749/2014/0419

FraAiJe, R.H.B., Artal, P., Van Bakel, B.W.M., Jagt, J.W.M. \& KLOMPMAKer, A.A. 2013. An array of sixth abdominal tergite types of paguroid anomurans (Crustacea) from the mid-Cretaceous of Navarra, northern Spain, 109-117. In Mulder, E.W.A., JAGT, J.W.M. \& SchulP, A.S. (eds) The Sunday's child of Dutch earth sciences - a tribute to Bert Boekschoten on occasion of his $80^{\text {th }}$ birthday. Netherlands Journal of Geosciences 92.

Fraaije, R.H.B., Klompmaker, A.A. \& Artal, P. 2012. New species, genera and a family of hermit crabs (Crustacea, Anomura, Paguroidea) from a mid-Cretaceous reef of 
Navarra, northern Spain. Neues Jahrbuch für Geologie und Paläontologie, Abhandlungen 263, 85-92. DOI 10.1127/0077-7749/2012/0213

Fraaije, R.H.B., Krzemiński, W., Van Bakel, B.W.M., KRZEMińsKA, E. \& JAGT, J.W.M. 2014. New Late Jurassic symmetrical hermit crabs from the southern Polish Uplands and early paguroid diversification. Acta Palaeontologica Polonica 59, 681-688.

Glaessner, M.F. 1960. The fossil decapod Crustacea of New Zealand and the evolution of the order Decapoda. New Zealand Geological Survey, Paleontological Bulletin 31, 1-79.

Hoyoux, C. 2010. Crustacés décapodes de bois coulés en océan profond: régimes alimentaires et symbioses microbiennes. $\mathrm{PhD}$ thesis, Faculté des Sciences, Université de Liège, Liège.

JURAČIĆ, M. 1979. Dubina sedimentacije "Lapora s rakovicama" iz odnosa planktonskih i bentickih foraminifera [Depth of sedimentation of "Marl with Crabs" estimated from the ratio between planktonic and benthic foraminifera]. Geološki vjesnik $31,61-67$.

LAMARCK, J.B. 1818. Histoire naturelle des animaux sans vertèbres 5. 612 pp. J.B. Baillière, Paris.

LAtreille, P.A. 1802. Histoire naturelle, générale et particulière, des crustacés et des insectes 3.408 pp. F. Dufart, Paris.

Lemaitre, R. 1995. A review of the hermit crabs of the genus Xylopagurus A. Milne-Edwards, 1880 (Crustacea: Decapoda: Paguridae), including descriptions of two new species. Smithsonian Contributions to Zoology 570, 1-27. DOI 10.5479/si.00810282.570.i

Lemaitre, R. \& Campos, N.H. 1993. Two new hermit crabs (Crustacea: Decapoda: Paguridae) from the Caribbean Sea. Proceedings of the Biological Society of Washington 106, 554-565.

LocATELLI, E.R. 2012. Experimental taphonomy of decapod crustaceans: assessing the effects of pre-burial processes. Geological Society of America 34, Annual Meeting, Abstracts with Programs, 102. Charlotte, North Carolina, USA.

Lovrich, G.A., CAlcagno, J.A. \& SMith, B.D. 2003. The barnacle Notobalanus flosculus as an indicator of the intermolt period of the male lithodid crab Paralomis granulosa. Marine Biology 143, 143-156. DOI 10.1007/s00227-003-1033-8

MacLeay, W.S. 1838. On the brachyurous decapod Crustacea brought from the Cape by Dr. Smith, 53-71. Illustrations of the Annulosa of South Africa; being a portion of the objects of Natural History chiefly collected during an expedition into the interior of South Africa, under the direction of Dr. Andrew Smith, in the years 1834, 1835, and 1836; fitted out by "The Cape of Good Hope Association for Exploring Central Africa”. Smith Elder, London.

Macpherson, E., Richer de Forges, B., Schnabel, K., Samadi, S., Boisselier, M.C. \& Garcia-Rubies, A. 2010. Biogeography of the deep-sea galatheid squat lobsters of the Pacific Ocean. Deep-Sea Research Part I: Oceanographic Research Papers 57(2), 228-238. DOI 10.1016/j.dsr.2009.11.002

Marinčić, S., Šparica, M., Tunis, G. \& Uchman, A. 1996. The Eocene flysch deposits of the Istrian peninsula in Croatia and Slovenia: regional, stratigraphic, sedimentological and ichnological analyses. Annals for Istrian and Mediterranean Studies 9, 136-156.
Martini, E. 1971. Standard Tertiary and Quaternary calcareous nannoplankton zonation, 739-785. In FARINACCI, A. (ed.) Proceedings of the II Planktonic Conference, Roma. Tecnoscienza, Rome.

M'Coy, F. 1849. On the classification of some British fossil Crustacea, with notices of new forms in the University Collection at Cambridge. Journal of Natural History 4(21), 161-179. DOI 10.1080/03745486009494810

MıкUŽ, V. 2002. Nova najdba rakovice Harpactoxanthopsis quadrilobata (Desmarest) v eocenskem flišu pri Gračišću blizu Pazina v Istri [New finding of crab Harpactoxanthopsis quadrilobata (Desmarest) in the Eocene flysch at Gračišće near Pazin in Istria (Croatia)].Geologija 45, 97-102.

MıKUŽ, V. 2003. Lophoranina marestiana iz srednjeeocenskih flišnih plasti pri Gračišću v Istri [Lophoranina marestiana from Middle Eocene flysch beds at Gračišce in Istria, Croatia]. Geologija 47, 23-27.

MikUŽ, V. 2005. Eocenski ježinci Istre [Eocene echinoids from Istria], 105-106. In Velić, I., Vlahović, I. \& Biondić, R. (eds) Abstract Book, $3^{\text {rd }}$ Croatian Geological Congress. Zagreb.

MıкUŽ, V. 2006. Novi najdbi polža rodu Velates iz eocenskega fliša Goriških brd in Gračišća v Istri [The new findings of Velates snail from Eocene flysch in Goriška brda and Gračišće in Istria]. Geologija 49, 53-60.

MikuŽ, V. 2008a. Ostanek eocenske gorgonarijske korale iz okolice Gračišća pri Pazinu v Istri [Eocene gorgonacean coral remain from surroundings of Gračišće near Pazin, Istria]. Razprave 4. razreda SAZU 49, 51-63.

MıкUZ̆, V. 2008b. Serpulidni črv Rotularia spirulaea iz eocenskih plasti pri Gračišću v Istri, Hrvaška [The serpulid worm Rotularia spirulaea from Eocene beds near Gračišce in Istria, Croatia]. Geologija 51, 161-168.

MıKUŽ, V. 2010a. Loforanine iz eocenskih plasti osrednje Istre [Lophoranina from Eocene beds in central Istria, Croatia]. Geologija 53, 47-54. DOI 10.5474/geologija.2010.004

MıKUŽ, V. 2010b. Gorgonarijska korala iz Gračišća pri Pazinu v Istri na Hrvaškem [Gorgonacean coral from Gračišće near Pazin in Istria, Croatia]. Folia biologica et geologica 51, $5-15$.

MikuŽ, V., BARTol, M. \& Šoster, A. 2014. Eocenski morski ježki iz okolice Gračišća pri Pazinu v osrednji Istri [The Eocene sea urchins from vicinity of Gračišće near Pazin in central Istria, Croatia]. Folia biologica et geologica 55, 5-50.

Milne-Edwards, A. 1862. Monographie des crustacés de la famille cancériens. Annales des Sciences naturelles, Zoologie 4(18), 31-85.

Milne-Edwards, A. 1880. Études préliminaires sur les crustacés, 1-68. Reports on the results of dredging, under the supervision of Alexander Agassiz, in the Gulf of Mexico, and in the Caribbean Sea, 1877, '78, '79, by the United States Coast Survey Steamer "Blake," Lieut.-Commander CD. Sigsbeee, U.S.N., and Commander J. R. Bartlett, U.S.N., Commanding, VIII. Bulletin of the Museum of Comparative Zoology 8.

OKADA, H. \& BUKRY, D. 1980. Supplementary modification and introduction of code numbers of the low latitude coccolith biostratigraphic zonation. Marine Micropaleontology 5, 321-325. DOI 10.1016/0377-8398(80)90016-X

PAVŠIČ, J. \& PREMEC FuČEK, V. 2000. Calcareous nannoplankton and planktonic foraminiferal zones during the middle and up- 
per Eocene of the "Transitional Beds" on the Adriatic platform, 22-23. In Trevisani, E. (ed.) $5^{\text {th }}$ Meeting IGCP 393 IUGS-UNESCO, Shallow water benthic communities at the Middle-Upper Eocene boundary (Southern and North-Eastern Italy, Slovenia, Croatia, Hungary). Museo Civico di Storia Naturali Ferrara, Ferrara.

Pilsbry, H.A. 1916. The sessile barnacles (Cirripedia) contained in the collections of the U.S. National Museum; including a monograph of the American species. Bulletin of the United States National Museum 93, 1-366.

DOI 10.5479/si.03629236.93.1

PoInAR, G. JR. \& Columbus, J.T. 2013. Alarista succina gen. et sp. nov. (Poaceae: Bambusoideae) in Dominican amber. Historical Biology 25, 691-696.

DOI 10.1080/08912963.2012.742891

ProvenZano, A.J. JR. 1971. Biological results of the University of Miami deep-sea expeditions, 73: Zoeal development of Pylopaguropsis atlantica Wass, 1963, and evidence from larval characters of some generic relationships within the Paguridae. Bulletin of Marine Science 21, 237-255.

Renema, W. 2007. Fauna development of larger benthic foraminifera in Cenozoic of Southeast Asia, 179-214. In Renema, W. (ed.) Biogeography, Time and Place: Distributions, Barriers and Islands. Topics in Geobiology 29. Springer Netherlands, Leiden.

Renema, W., Bellwood, D.R., Braga, J.C., Bromfield, K., Hall, R., Johnson, K.G., Lunt, P., Meyer, C.P., McGonagle, L.B., Morley, R.J., O’Dea, A., TodD, J.A., Wesselingh, F.P., Willson, M.E.J. \& PANDOlfi, J.M. 2008. Hopping hot-spots: global shifts in marine biodiversity. Science 321, 654-657. DOI 10.1126/science.1155674

Robin, N. 2015. Epibioses de crustacés décapodes fossiles: apports paléoécologiques, identification de paléosymbioses et évolution au cours du temps. 274 pp. $\mathrm{PhD}$ thesis, Muséum national d'Histoire naturelle Paris.
Robin, N., Petit, G. \& Charbonnier, S. 2015. A newly recognized Mesozoic-Recent interspecific association: calcifying bacteria on decapod crustaceans. Lethaia 48, 463-473. DOI 10.1111/let.12120

Saint Laurent-Dechancé, M. De 1966. Remarques sur la classification de la famille des Paguridae et sur la position systématique d'Iridopagurus de Saint Laurent. Diagnose d'Anapagrides gen. nov. Bulletin du Muséum national d'Histoire naturelle Paris 38, 257-265.

Schweitzer, C.E., Ćosović, V. \& Feldmann, R.M. 2005. Harpactocarcinus from the Eocene of Istria, Croatia, and the paleoecology of the Zanthopsidae Via, 1959 (Crustacea: Decapoda: Brachyura). Journal of Paleontology 79, 663-669. DOI 10.1666/0022-3360(2005)079[0663:HFTEOI]2.0.CO;2

StrömBERG, C.A. 2011. Evolution of grasses and grassland ecosystems. Annual Review of Earth and Planetary Sciences 39, 517-544. DOI 10.1146/annurev-earth-040809-152402

VIA, L. 1959. Decápodos fósiles del Eoceno español. Boletín Instituto Geológico y Minero de España 70, 331-402.

WALton, B.C. 1950. Some new and rare Pacific pagurids. Journal of the Washington Academy of Sciences 40(6), 188-193.

Wang, L., Jacques Frédéric, M.B., TaO, S., Yaowu, X., Shitao, Z. \& Zhekun, Z. 2013. The earliest fossil bamboos of China (middle Miocene, Yunnan) and their biogeographical importance. Review of Palaeobotany and Palynology 197, 253-265. DOI 10.1016/j.revpalbo.2013.06.004

Waugh, D.A., Feldmann, R.M., Crawford, R.S., Jakobsen, S.L. \& Thomas, K.B. 2004. Epibiont preservational and observational bias in fossil marine decapods. Journal of Paleontology $78,961-972$.

DOI 10.1666/0022-3360(2004)078<0961:EPAOBI >2.0.CO;2

Žıvkovic, S. \& Glumac, B. 2007. Paleoenvironmental reconstruction of the Middle Eocene Trieste-Pazin Basin from benthic foraminiferal assemblages. Micropaleontology 53, 285-310. DOI 10.2113/gsmicropal.53.4.285 